\title{
166. Studies on the Alkaline Phosphatase of Sheep Serum
}

\author{
By Shoji Akagi, Seiki Watanabe,*) and Shozo Suzuki*) \\ (Comm. by Tanemoto FuruhatA, M. J. A., Nov. 12, 1971)
}

The alkaline phosphatases of sheep sera were divided into three molecular forms, A, B and C by starch-gel electrophoresis (Rendel and Stormont 1964). They also demonstrated that the alkaline phosphatase variants are closely related to the blood groups of the $\mathrm{R}-\mathrm{O}-\mathrm{i}$ system, and specially, $\mathrm{O}$ substance may take part in the production of the $\mathrm{B}$ phosphatase.

The present experiments were carried out to confirm the properties and the inheritance mode of alkaline phosphatase of sheep sera.

Materials and methods. Serum sample. Sheep sera were collected from Corriedale breeds and the other of the three flocks in the Hokkaido National Agricultural Experimental Station, the Takigawa Institute of Animal Industry and the Iwate Stock Breeding Station. The sera were stored for 6-18 months in the $-20^{\circ} \mathrm{C}$ deep freezer.

Electrophoresis. The alkaline phosphatase was assayed by starch-gel and polyacrylamide-gel electrophoresis. Starch-gel electrophoresis was performed by the discontinuous buffer system (Poulik 1967). Gel buffer contained $9.40 \mathrm{~g}$ tris (hydroxymethyl) aminomethane, $1.05 \mathrm{~g}$ citric acid and $2.00 \mathrm{~g}$ boric acid per litter of solution at the $\mathrm{pH} 8.65$ and electric buffer, $0.3 \mathrm{M}$ boric and $0.06 \mathrm{M} \mathrm{NaOH}$ per litter of solution, $\mathrm{pH} 8.45$. To the $11 \%$ starch-gel with interior dimensions of $6 \mathrm{~mm} \times 60 \mathrm{~mm} \times 170 \mathrm{~mm}$ the electric current of $40 \mathrm{~mA}$ was transmitted for 5 hours. Polyacrylamide-gel electrophoresis was performed by the discontinuous buffer system contained $9.2 \mathrm{~g}$ tris (hydroxymethyl) aminomethane, 1.05 citric acid per litter of solution. Gel density of supporting thin layer was $5 \%$. To the polyacrylamidegel with interior dimensions of $2 \mathrm{~mm} \times 110 \mathrm{~mm} \times 160 \mathrm{~mm}$ the electric current of $40 \mathrm{~mA}$ was transmitted for 3.5 hours at $4{ }^{\circ} \mathrm{C}$.

After electrophoresis, the starch-gel was sliced longitudinally and the polyacrylamide-gel was incubated for 2 hours in a staining solution containing sodium $\alpha$-naphthylphosphate and naphthanil diazo blue $B$ as active ingredients.

Results, Classification of alkaline phosphatase phenotypes. Zymograms of alkaline phosphatases of 9 sheep sera by the starch-gel

Institute of Animal Serology, Tokyo University of Agriculture, Setagaya, Tokyo. 


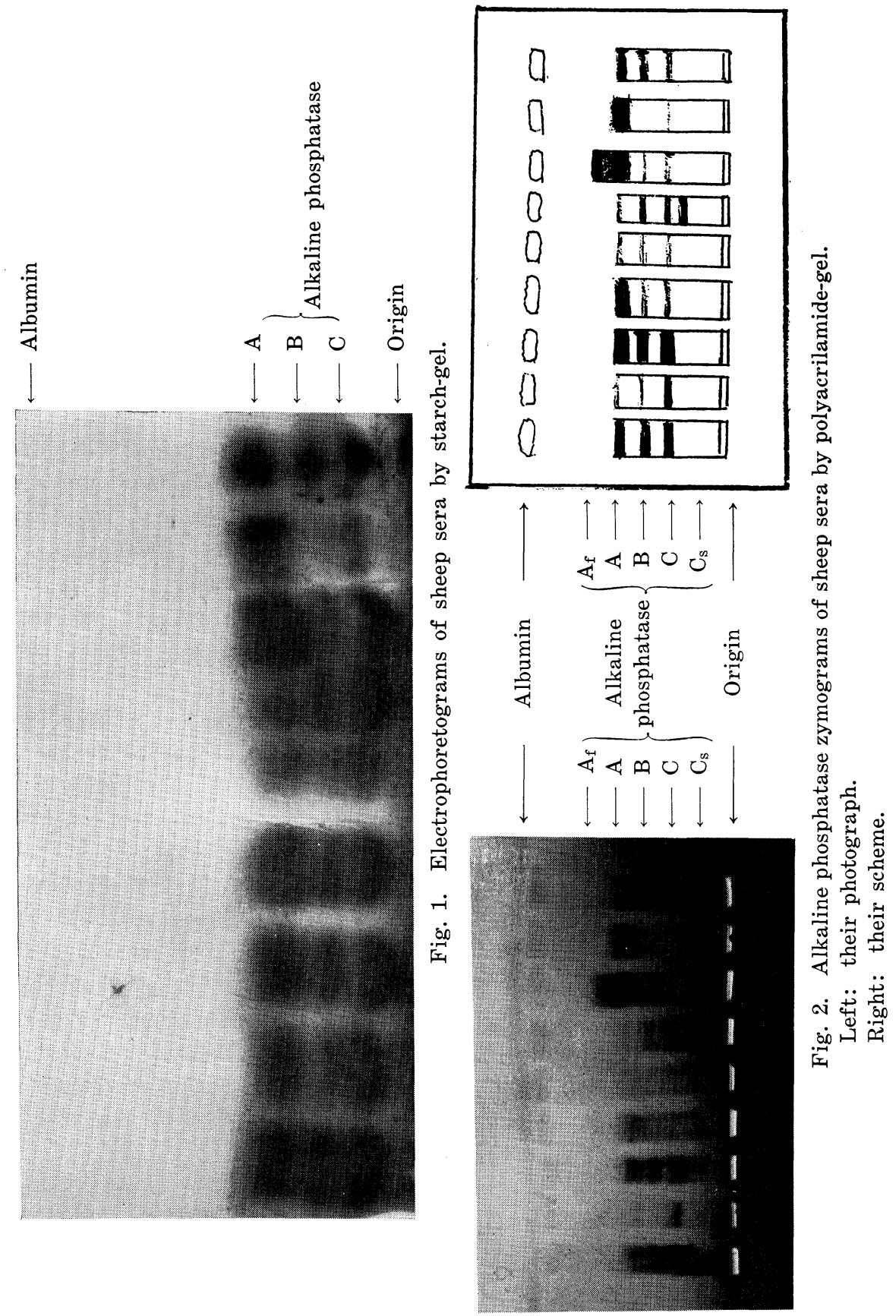




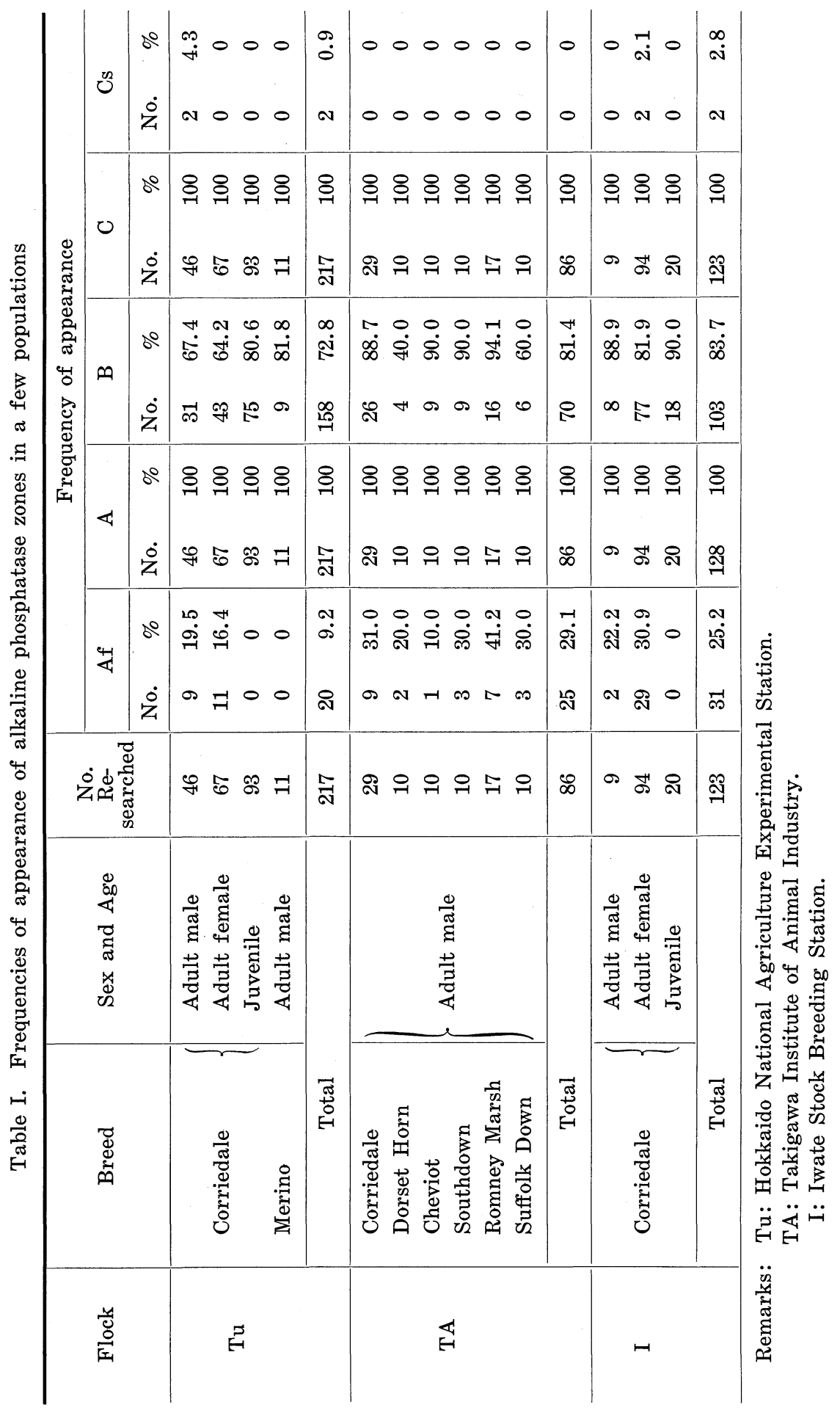


electrophoresis were shown in Fig. 1. Alkaline phosphatases were divided into three different zones, which are recognized to be the same as A, B and C zones reported by Rendel et al. Moreover, two new zones of alkaline phosphatase were observed in the zymograms of the same samples by the polyacrylamide-gel electrophoresis as shown in Fig. 2. One migrated faster than A-zone and the other slower than C-zone. The former is called as Af-zone and the latter as Cs-zone.

Frequencies of appearance of alkaline phosphatases. The frequencies of appearance of alkaline phosphatase were examined on three flocks of sheep (Table I). Af-zone was not present in populations of male and female lambs of 2-7 months of age. The frequencies of Af-zone in adult sheep were $0-40 \%$; there was a slight difference among breeds and sexes. C-zone was observed in all sheep of each flock. The frequencies of appearance of B-zone were about $80 \%$. No difference was observed among three flocks, breeds and sexes, respectively. Cs-zone was rarely present in the adult sheep only, about $2 \%$.

Activity of alkaline phosphatase. The intensity of 217 Corriedales was compared by the naked eye from the view point of age and sex. The intensities of $\mathrm{A}$ and B-zones were much stronger in lambs than those in adult sheep. The intensity of C-zone in lambs was much weaker than that in adult sheep. Also, those Af and Cs-zones could not be analized, since their frequencies of appearance were few.

Table II. Distribution of alkaline phosphatase phenotypes in the offsprings from three different matings of $\mathrm{B}$ zone

\begin{tabular}{c|c|cc|c}
\hline \multirow{2}{*}{ Mating type } & \multirow{2}{*}{$\begin{array}{c}\text { Number of } \\
\text { mating }\end{array}$} & \multicolumn{2}{|c|}{ Distribution of phenotype } & \multirow{2}{*}{ Total } \\
\cline { 2 - 4 } & & $\mathrm{B}^{+}$ & $\mathrm{B}^{-}$ & \\
\hline $\mathrm{B}^{+} \times \mathrm{B}^{+}$ & 69 & 65 & 7 & 72 \\
$\mathrm{~B}^{+} \times \mathrm{B}^{-}$ & 45 & 32 & 14 & 46 \\
$\mathrm{~B}^{-} \times \mathrm{B}^{-}$ & 2 & 0 & 2 & 2 \\
\hline Total & 116 & 97 & 23 & 120 \\
\hline
\end{tabular}

Inheritance mode of B-zone. The distribution of offsprings obtained from three matings between individuals with $\mathrm{B}$ band $\left(\mathrm{B}^{+}\right)$ and those without $\mathrm{B}$ band $\left(\mathrm{B}^{-}\right)$is shown as Table II. As shown in the table, the offsprings of $\mathrm{B}^{+}$and $\mathrm{B}^{-}$were obtained from matings by $\mathrm{B}^{+} \times \mathrm{B}^{+}$and $\mathrm{B}^{+} \times \mathrm{B}^{-}$, respectively; and $\mathrm{B}^{-}$was obtained only from matings by $\mathrm{B}^{-} \times \mathrm{B}^{-}$. From these results, it was conjectured that $\mathrm{B}^{+}$was genetically controlled by the dominant gene to $\mathrm{B}^{-}$. 
Table III. The observed values compared with the expected ones

\begin{tabular}{c|c|c|c}
\hline Mating type & $\mathrm{B}^{+}$ & $\mathrm{B}^{-}$ & $\mathrm{X}$-test \\
\hline \multirow{2}{*}{$\mathrm{B}^{+} \times \mathrm{B}^{+}$} & 65.30 & 6.70 & $\begin{array}{l}\mathrm{X}^{2}=0.0148 \\
\mathrm{df}=1 \\
\mathrm{p}=0.95-0.90\end{array}$ \\
\hline & 65 & 7 & $\mathrm{X}^{2}=0.0001$ \\
$\mathrm{~B}^{+} \times \mathrm{B}^{-}$ & 31.97 & 14.03 & $\mathrm{df}=1$ \\
& 32 & 14 & $\mathrm{p}=>0.99$ \\
\hline $\mathrm{B}^{-} \times \mathrm{B}^{-}$ & 0 & 2 & \\
\hline
\end{tabular}

Remarks: The upper: The expected value.

The lower: The observed value.

Table IV. Gene frequencies in populations of Corriedale and other breeds

\begin{tabular}{c|l|c|cc}
\hline \multicolumn{2}{c|}{$\begin{array}{c}\text { Population and } \\
\text { Breed }\end{array}$} & $\begin{array}{c}\text { No. of } \\
\text { animals }\end{array}$ & \multicolumn{2}{c}{ Gene frequency } \\
\cline { 3 - 5 } $\mathrm{Tu}$ & Corriedale & 206 & 0.477 & $\mathrm{q}$ \\
\hline \multirow{3}{*}{$\mathrm{T}$} & 11 & 0.573 & 0.427 \\
& Merino & 29 & 0.664 & 0.336 \\
& Corriedale & 10 & 0.225 & 0.775 \\
& Dorset Horn & 10 & 0.684 & 0.316 \\
& Cheviot & 10 & 0.684 & 0.316 \\
& Southdown & 17 & 0.757 & 0.243 \\
& Romney Marsh & 10 & 0.368 & 0.632 \\
\hline \multirow{2}{*}{$\mathrm{I}$} & Suffolk Down & 123 & 0.595 & 0.405 \\
\hline
\end{tabular}

Remarks: $p$ : Gene frequencies of APase B.

$\mathrm{q}$ : Gene frequencies of APase b.

Therefore, the observed and the expected values of appearance of alkaline phosphatase types in offsprings were calculated according to the expected frequencies (by Snyder), which are shown in Table III. The observed values in each mating are almost similar to the expected ones. So, $\mathrm{B}^{+}$type is dominant to $\mathrm{B}^{-}$type.

The symbols of the dominant and the recessive genes of this new system were named APase B and APase b, respectively, by authors. The gene frequencies were calculated in a few populations of Corriedale and the other breeds (Table IV).

Summary. 1. By zymograms of the polyacrilamide-gel electrophoresis, the new two zones, Af and Cs-zones were recognized in 
addition to the same three zones as A, B and C-zones which were reported by Rendel et al.

2. The frequencies of appearance of alkaline phosphatase Af, $\mathrm{A}, \mathrm{B}, \mathrm{C}$ and $\mathrm{Cs}$ were as follows:

(1) Af-zone was recognized in adult sheep only. The frequencies of appearance of Af-zone in a few populations were $0-40 \%$, and a slight difference due to breeds was observed.

(2) A and C-zones were observed in all kinds of sheep.

(3) The frequencies of appearance of B-zone were about $80 \%$.

(4) Cs-zone was rarely observed in adult sheep only.

3. The intensities of $\mathrm{A}$ and B-zones in lamb were much stronger than those in adult sheep. Also, that of C-zone in lamb was much weaker than that in adult sheep.

4. $\mathrm{B}^{+}$type is dominant to $\mathrm{B}^{-}$type.

5. The symbols of the dominant and the recessive genes of phosphatase were named APase B and APase b, respectively.

Acknowledgment. The authors thank greatly Dr. T. Furuhata, Director of National Research Institute of Police Science, and Dr. S. Ikemoto, National Research Institute of Police Science, for their valuable advice and kindness.

\section{References}

1) Ashton, G. C., D. G. Gilmour, C. A. Kiddy, and F. K. Kristjansson (1967): Genetics, 156, 353-362.

2) Ashton, G. C. (1957): Nature, 180, 917-919.

3) Tsuneo, Abe (1967): Jap. J. Zootech. Sci., 37, 157-165.

4) Neiman-Sørenser, A., C. Rendel, and W. H. Stone (1954): Immuno., 73, 407.

5) Poulik, M. D. (1957): Nature, 180, 1477.

6) Rendel, J., and C. Stormont (1964): Biol. Med., 115, 853-856.

7) Rendel, J., O. Aalund, R. A. Freedland, and F. Møller (1964): Genetics, 50, 973-986.

8) Snyder, L. H. (1946): The Principle of Heredity (3 ed.), 348-371. Boston, Heath.

9) Stormont, C. (1949): Proc. Nat. Acad. Sci., 35, 232. 